\title{
Timing of Institutional Bias Challenges to Arbitration
}

\author{
Roger J. Perlstadt $\dagger$
}

Private, voluntary arbitration is employed widely in the United States.' Arbitration occurs when parties agree to adjudicate a dispute before a neutral decisionmaker who is neither a judge nor an administrative official. ${ }^{2}$ Parties to a dispute can enter into an ad hoc agreement to arbitrate once a dispute has arisen, or they can enter into a pre-dispute arbitration agreement in which they agree in advance to submit to arbitration disputes that may subsequently arise. ${ }^{3}$ In either case, arbitration agreements are contracts, ${ }^{4}$ and parties are free to agree on whatever procedural and substantive rules they wish to have applied toward the resolution of their dispute. This means that parties can either create their own arbitration rules and select their own arbitrators or agree to submit their disputes to an arbitration organization that has existing procedures and panels of arbitrators. ${ }^{6}$ Regardless of the system to which parties ultimately agree, they will be bound by the arbitrator's decision.?

Historically, courts were hostile to arbitration agreements and often refused to enforce them. ${ }^{8}$ In 1925 , however, Congress enacted the Federal Arbitration Act ("FAA")" "to reverse the longstanding judicial hostility to arbitration agreements that had existed at English common law and had been adopted by American courts." ${ }^{10}$ The FAA treats arbitration agreements as being as enforceable as any other

† B.A. 1997, Carleton College; J.D. 2002, The University of Chicago.

1 See Leonard L. Riskin and James E. Westbrook, Dispute Resolution and Lawyers 503-04 (West 2d ed 1997) (collecting sources outlining the use of private arbitration in a wide variety of contexts).

2 See id at 502.

See id.

4 See First Options of Chicago Inc v Kaplan, 514 US 938, 943 (1995) ("[A]rbitration is simply a matter of contract between the parties; it is a way to resolve those disputes ... that the parties have agreed to submit to arbitration.").

5 See Riskin and Westbrook, Dispute Resolution at 502 (cited in note 1) ("Private arbitration systems are diverse because one of the features of private arbitration is that the parties have considerable freedom in designing the process and providing the substantive standards used by the arbitrator in making a decision.").

6 See id at 502-03.

See id at 502.

See id at 515.

9 Pub L No 68-401, 43 Stat 883 (1925), codified as amended at 9 USC $\$ 1$ et seq (2000).

10 Gilmer v Interstate/Johnson Lane Corp, 500 US 20, 24 (1991). 
contract $^{11}$ and orders federal district courts to compel arbitration when one party has failed, neglected, or refused to comply with an arbitration agreement. ${ }^{12}$

Despite this "liberal federal policy favoring arbitration agreements,"13 a party who is ostensibly bound by an arbitration agreement but wishes not to have a dispute arbitrated may be able to obtain relief from a federal district court. ${ }^{14}$ This relief can be sought either prior to the arbitration as an action to avoid the arbitration completely (and have the underlying dispute resolved by a court), ${ }^{15}$ or after the arbitration as an action to change any decision made by the arbitrator. Whether a court permits a party to challenge an arbitration agreement before or after the arbitration proceeding has important consequences for both parties. Allowing challenges in court prior to arbitration opens the floodgates to litigation, thus defeating the purpose of entering into an arbitration agreement in the first place. ${ }^{17}$ On the other hand, requiring a party to wait until after arbitration is complete to raise a challenge in court forces that party to participate in a proceeding to which they may not have validly agreed to submit. ${ }^{18}$

Whether relief can be sought in court before or after the arbitration hearing generally depends on the type of challenge raised. Federal district courts have entertained challenges prior to the commencement of arbitration based on ordinary contract principles such as lack of consideration, unconscionability, and the adhesion contract doctrine." In addition, when the underlying dispute involves the federal statutory rights of one of the parties, federal courts have heard challenges prior to arbitration based on that party's inability to vindicate its statutory rights effectively through arbitration. ${ }^{20}$

11 See 9 USC § 2 ("[Arbitration agreements] shall be valid, irrevocable, and enforceable, save upon such grounds as exist at law or in equity for the revocation of any contract.").

12 See 9 USC \& 4 (stating that if a valid arbitration agreement exists with which one party has not complied, "the court shall make an order summarily directing the parties to proceed to arbitration in accordance with the terms" of the agreement).

13 Gilmer, 500 US at 25, quoting Moses H. Cone Memorial Hospital v Mercury Construction Corp, 460 US 1, 24 (1983).

14 The FAA does not grant general subject matter jurisdiction over disputes involving arbitration agreements. Thus, there must be an independent basis for federal jurisdiction, such as diversity. See Moses $H$. Cone, 460 US at 25 n 32 ("[The FAA] creates a body of federal substantive law establishing and regulating the duty to honor an agreement to arbitrate, yet it does not create any independent federal question jurisdiction.... [T] here must be diversity of citizenship or some other independent basis for federal jurisdiction.").

15 See 9 USC $\S \S 2,4$ (outlining procedures for determining whether a valid agreement to arbitrate exists).

16 See 9 USC $\$ 10$ (outlining procedures for vacatur of an arbitration award).

17 See Part II.B.3.

18 See Part II.A.3.

19 See Part II.A.1.

20 See Part II.A.2. 
On the other hand, two types of challenges to arbitration agreements may be raised only after arbitration has been completed and a decision rendered. These two challenges are attacks on the actual arbitration based on "evident partiality" of the arbitrator" and "fundamental unfairness" of the arbitration.

Parties to an arbitration agreement may also attempt to challenge the agreement based on institutional bias of the chosen arbitration system. Institutional bias challenges allege the general tendency of an arbitration forum to find consistently in favor of one type of participant over another, for example, employers over employees. ${ }^{23}$ Unlike challenges to arbitration based on contract principles or an inability to vindicate statutory rights, which may be brought prior to arbitration, or those based on "evident partiality" or "fundamental unfairness," which may only be brought post-arbitration, it is unclear whether institutional bias challenges may properly be raised before or after arbitration. On first impression it may seem that such challenges better match with the "evident partiality" or "fundamental unfairness" challenges that can only be raised post-arbitration. This Comment argues, however, that the actual best fit is with those challenges that can be raised prior to arbitration, and that institutional bias challenges should be heard before arbitration commences.

Part I explains and gives examples of institutional bias challenges that have been leveled against various arbitration systems as well as the current conflict regarding proper timing of such challenges. Part II explains the timing of other types of challenges to arbitration and the justifications for the different timing allowances. Part II.A describes those challenges that may be brought prior to arbitration, and Part II.B describes those challenges that may be brought only after arbitration. Finally, Part III compares institutional bias challenges to those challenges discussed in Part II and concludes that courts should entertain institutional bias challenges prior to arbitration.

\section{INSTITUTIONAL BIAS CHALLENGES}

\section{A. Examples of Institutional Bias Allegations}

"Institutional bias" is a phrase often invoked but rarely defined. ${ }^{24}$ With respect to arbitration organizations, the term generally refers to

21 See Part II.B.1.

22 See Part II.B.2.

23 See Part I.

24 An electronic search of the ALLFEDS database in Westlaw revealed 144 federal cases using the term "institutional bias," but the term is not found in West's Federal Practice Words and Phrases Digest. See Federal Practice Digest 4th: Words and Phrases H-K (West 1999 \& Supp 2001). 
a tendency for arbitration outcomes to favor one class of participants over another. The bias is considered institutional because the causes of the unbalanced outcomes may be widely diffused throughout the entire arbitral system.

Both commentators and litigants have leveled charges of institutional bias against various arbitration organizations. Consider, for example, the Internet Corporation for Assigned Names and Numbers ("ICANN"). ICANN's uniform dispute resolution policy governs disputes between domain name registrants and trademark holders with whose trademark the domain name may interfere. Two independent studies of ICANN's resolution system indicate that trademark holders have a statistical advantage over registrants in arbitration. ${ }^{25}$ Under ICANN's resolution system, only trademark holders may launch complaints. ${ }^{27}$ The trademark holder brings a complaint with one of four arbitration companies, paying a fee of approximately $\$ 1,500 .^{23}$ Thus, it is in the arbitration providers' best interests to favor trademark holders in order to attract their business in the future. Studies by Milton Mueller at Syracuse University and Michael Geist at the University of Ottawa confirm this suspicion, finding two major areas where bias is evident in the system. ${ }^{2}$

First, when trademark holders are allowed to choose the arbitration company, they engage in significant forum shopping, bringing most cases to companies that tend to find in favor of the complainant. $^{30}$ Notably, following the publication of Mueller's report, the arbi-

25 See ICANN Uniform Domain Name Dispute Resolution Policy, available online at $<$ http://www.icann.org/udrp/udrp.htm> (visited July 5, 2002). This system is not identical to the traditional pre-dispute arbitration agreement in which both parties to a potential dispute agree to submit to mandatory arbitration (as in an employment context, for example, where employer and employee both sign the arbitration agreement). In this case, the domain name registrant signs an agreement with a registration company. The registrant agrees to submit to arbitration disputes with trademark holders who are not signatories to the registration agreement. See, for example, DomainRegistry.com Inc. Domain Registration Form, available online at <https:// www.domainregistry.com/register/index.html> (visited July 5, 2002) ("By submitting this registration, you acknowledge, accept, and agree, that you understand the following: . . . Registrant agrees that if the registration of its domain name is challenged by any third party, the Registrant will be subject to the provisions specified in the ICANN Uniform Domain Name Dispute Resolution Policy.").

26 See Kim Honey, Master of His Domain, The Globe and Mail R1 (Aug 22, 2001) (describing studies performed by Milton Mueller at Syracuse University's Convergence Center and Michael Geist at the University of Ottawa).

27 See id.

28 See id.

29 See id.

30 Geist found that WIPO, one of the arbitration organizations, attracted 58 percent of cases and decided in favor of the trademark holders 82 percent of the time. See id. Geist also found that 90 percent of trademark holders choose the two arbitration providers that render the most pro-complainant decisions. See Michael Geist, How Bias Besets Domain Cases, The Globe and Mail B12 (Aug 23, 2001). 
tration organization with the smallest statistically significant market share and the largest propensity for deciding in favor of registrants saw a drop in business as trademark holders took their complaints to the two organizations that appeared most favorable to complainants. ${ }^{31}$

Second, within the arbitration companies the selection process for arbitrators appears biased in favor of trademark holders. Disputes are heard by either a panel of three arbitrators selected by the parties or a single arbitrator chosen by the arbitration provider. ${ }^{32}$ When a panel of arbitrators hears the case, trademark holders prevail about 60 percent of the time. ${ }^{33}$ When a single arbitrator chosen by the arbitration provider hears it, that figure jumps to 83 percent. ${ }^{34}$ This bias may result from the fact that although assignment of single arbitrators is supposed to be random, it in fact is not.

Litigants have leveled similar charges against various other arbitration organizations. The New York Stock Exchange arbitration system has been accused of being dominated by the securities industry such that in disputes between firms and individuals, the firms "selec[t] the entire arbitrator pool, appoin[t] the individual arbitration panels, and mak[e] important procedural and discovery decisions. ${ }^{36}$ The National Grain \& Feed Association ("NGFA") arbitration system has also been accused of structural bias in that NGFA members serve as arbitrators, placing farmers "in the unenviable position of having to attempt to persuade NGFA members that a widespread practice of the association's membership is illegal. ${ }^{37}$

31 See Honey, Master of His Domain, The Globe and Mail at R1 (cited in note 26). Commentators have criticized this repeat-player problem in other dispute resolution systems, such as compulsory arbitration of employment disputes. See, for example, Richard A. Bales, Compulsory Arbitration: The Grand Experiment in Employment 128 (Cornell 1997). Bales notes two problems arising from the fact that employers who often participate in arbitration face employees who are unlikely to have encountered arbitration before or to encounter it again. First, if the parties are given a choice of arbitrators, a repeat-player employer is likely to have more and better information about the arbitrators, allowing it to make a favorable selection. See id. Second, the knowledge that an employer is more likely than an employee to hire an arbitrator in the future may consciously or subconsciously induce the arbitrator to favor the employer. See id. 30).

32 See Geist, How Bias Besets Domain Cases, The Globe and Mail at B12 (cited in note

33 See id.

34 See id.

35 See id. Geist cites as an example the National Arbitration Forum ("NAF"). Although the NAF has 135 arbitrators, 53 percent of cases are heard by just six of them. These six arbitrators rule in favor of trademark holders 94 percent of the time. See id. See also Honey, Master of his Domain, The Globe and Mail at R1 (cited in note 26) (noting that Mueller, an outspoken critic of the ICANN process, has been on one of the provider's lists of potential arbitrators for two years and has never been assigned to a case on his own).

36 Rosenberg $v$ Merrill Lynch, Pierce, Fenner \& Smith, Inc, 995 F Supp 190, 211 (D Mass 1998), affd 163 F3d 53 (1st Cir 1998), vacd by 1999 US App LEXIS 7793 (1st Cir), substituted opinion at 170 F3d 1 (1st Cir 1999).

37 Harter v Iowa Grain Co, $220 \mathrm{F3d} 544,554$ (7th Cir 2000), quoting Brief for Appellants I 


\section{B. Circuit Split Over Timing of Institutional Bias Challenges}

Given that there is legitimate controversy about the institutional bias of various arbitration organizations, the question becomes when and how a party who has signed a pre-dispute arbitration agreement can challenge what it perceives to be an arbitration forum structurally biased in its opponent's favor. Courts are split on this question.

The Seventh Circuit has found that institutional bias claims must be postponed until the completion of arbitration. In Smith $v$ American Arbitration Association, Inc, ${ }^{33}$ a woman contracted to sell her controlling interest in a corporation for $\$ 65$ million. ${ }^{39}$ As part of the contract, she agreed to submit disputes to arbitration. ${ }^{40}$ When a dispute subsequently arose, the woman alleged that the arbitration system was biased because it made it easy for an all-male panel to be selected that would presumably be unsympathetic to her." The court called her challenge "premature," indicating that she could challenge the arbitration after proceedings were complete. The court reasoned that by placing an arbitration clause in their contract, the parties chose to trade certain procedural safeguards for savings in time and expense. ${ }^{43}$ One of the procedural safeguards given up was the power to challenge bias of the arbitration prior to the arbitral resolution of the dispute." Thus, the Seventh Circuit stated, "[t]he time to challenge an arbitration, on whatever grounds, including bias, is when the arbitration is completed and an award rendered."

On the other hand, two other circuit courts have indicated that there may be cases in which, prior to arbitration, a party could demonstrate structural bias to an extent that the court would refuse to compel arbitration. For example, in Floss v Ryan's Family Steak Houses, Inc ${ }^{46}$ employees tried to bring suit against their employer under the Fair Labor Standards Act and the Americans with Disabilities Act. ${ }^{47}$ As part of their employment contracts, however, the employees had signed arbitration agreements. ${ }^{40}$ In attempting to avoid arbitration, the employees argued that the arbitration procedures were biased in their

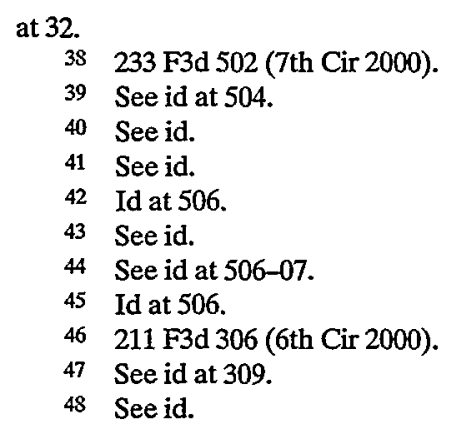


employer's favor. ${ }^{49}$ The Sixth Circuit ultimately refused to compel arbitration on other grounds. ${ }^{50}$ The court implied, however, that if there had not been other grounds for its decision, it would have considered the potential bias prior to deciding whether to compel arbitration. ${ }^{\text {s1 }}$ Thus it appears that the Sixth Circuit would hear certain institutional bias claims prior to arbitration.

Likewise, the First Circuit indicated that it would hear certain bias claims prior to arbitration. In Rosenberg $v$ Merrill Lynch, Pierce, Fenner \& Smith, Inc, ${ }^{\text {s2 }}$ the plaintiff alleged "structural infirmities" in the arbitration system that would hear her Title VII and ADEA complaints against her employer. ${ }^{53}$ Although the court compelled arbitration in that case, it did so because the evidence did not sufficiently establish bias. ${ }^{54}$ The First Circuit is therefore receptive to hearing certain institutional bias challenges prior to arbitration, as well as receptive to potentially refusing to compel arbitration in cases in which that bias can be sufficiently established. It noted that "[p]laintiffs are not required to take their claims to biased panels or through biased procedures." $"$ s

At first glance, institutional bias challenges may appear to be no different from "evident partiality" or "fundamental unfairness" challenges that parties may only raise after an arbitration proceeding. However, on further examination of the challenges that parties may raise before and after arbitration, institutional bias challenges appear to present a better fit, both in substance and in underlying justification, with those challenges raised prior to a proceeding.

\section{Timing of ARBitration Challenges Generally}

Although the proper timing of institutional bias challenges to arbitration is currently unclear, the law is fairly settled with respect to the timing of other types of challenges. Two types of challenges are permitted prior to arbitration. First, allegations that the arbitration agreement is not valid based on general contract principles are heard

49 See id at 313-14.

50 See id at 314 (invalidating the arbitration contract on the grounds that the promise to provide an arbitral forum was too vague and therefore illusory, and hence could not provide consideration for the contract).

51 See id ("Though we have concerns with ... the ... potential bias of [employer's] arbitral forum, we need not decide whether these deficits prevent the arbitration of [employee's] statutory claims.").

52170 F3d 1 (1st Cir 1999).

53 Id at 14 (noting that the plaintiff had claimed that the arbitrator was governed by the defendant).

54 See id at 16. Once the court found there was not sufficient evidence of bias, it then found that Merrill Lynch had not satisfied its obligations under the arbitration contract. See id at 20 .

55 Id at 16. 
pre-arbitration. Courts cannot compel parties to submit to an arbitration to which they did not agree. Thus, prior to compelling arbitration, a court must determine that the arbitration agreement is a valid contract. Second, allegations that the arbitration will not allow effective vindication of statutory rights are also heard pre-arbitration. Resolution of disputes involving statutory rights has an element of public interest to it. Whether one citizen is able to vindicate his statutory rights in any given situation is a matter of concern to all citizens. Thus, federal courts may, prior to arbitration, entertain arguments that arbitration would not allow for vindication of statutory rights.

Two other types of challenges to arbitration can be brought only after the completion of an arbitration proceeding. First, a party can challenge the proceeding based on the "evident partiality" of the arbitrator. This challenge means that a court can vacate an arbitration award if there is a reasonable impression that the arbitrator was biased. Second, a party can challenge an arbitration based on the "fundamental unfairness" of the proceedings. This challenge allows a court to vacate an award if the arbitration lacked some fundamental elements of fairness such as notice and an opportunity to be heard. These challenges are permitted only after the completion of arbitration for several reasons including respect for the arbitration agreement, and the difficulty in establishing partiality or unfairness of a proceeding before the proceeding has taken place.

\section{A. Challenges Prior to Arbitration}

Challenges prior to arbitration generally take the form of a defense to a motion to compel arbitration. The party seeking to arbitrate the underlying dispute brings the motion to compel. They may bring it either as part of a motion to dismiss or stay federal court proceedings if the other party brings the underlying dispute to federal court, ${ }^{\text {ss }}$ or as an independent action when the opposing party simply refuses to submit to arbitration.

56 See, for example, Hurlbut v Gantshar, 674 F Supp 385, 386 (D Mass 1987). In Hurlbut, plaintiff investor brought suit in federal court against her broker alleging various acts stemming from mismanagement of her account. See id. The broker then sought to stay the proceedings and compel arbitration based on the fact that plaintiff had signed an agreement to arbitrate any disputes when she opened her account. See id at 387.

57 See, for example, Associated Brick Mason Contractors of Greater New York, Inc v Harrington, $820 \mathrm{~F} 2 \mathrm{~d} 31,34$ (2d Cir 1987). In that case, the employer brought an action in district court to compel arbitration after the union failed to submit to the employer's demand for arbitration. See id. The union responded by challenging the arbitration, arguing, among other things, that the underlying dispute was outside the scope of the arbitration agreement. See id at 34-35. See also Prima Paint Corp v Flood and Conklin Manufacturing Co, 388 US 395, 404 (1967) (noting that federal district courts' review of challenges to arbitration agreements does not vary depending on which party originally invoked the assistance of the court). 
Challenges based on general contract principles are premised on the FAA. ${ }^{\$ 3}$ Pre-arbitration review of such challenges are justified on two grounds. First, an arbitrator lacks authority to adjudicate a dispute absent a valid contractual agreement to arbitrate. Second, waiting until after an arbitration has been completed adds nothing to the determination of whether there was a valid arbitration agreement.

Challenges based on an inability to vindicate statutory rights are premised on a line of Supreme Court cases beginning with Mitsubishi Motors Corp v Soler Chrysler-Plymouth, Inc, ${ }^{60}$ which held that statutory rights may be arbitrated so long as those rights can be adequately enforced. ${ }^{61}$ Pre-arbitration review of these challenges is justified on the grounds that the public has an interest in supplying an adequate forum for the enforcement of statutory rights and that post-arbitration review is an insufficient check on this forum. ${ }^{62}$

\section{Challenges based on general contract principles.}

Section 2 of the FAA indicates that an agreement to arbitrate between two parties "shall be valid, irrevocable, and enforceable, save upon such grounds as exist at law or in equity for the revocation of any contract." ${ }^{, 3}$ Thus, when a dispute arises between parties who are bound by an arbitration agreement, a party may challenge the agreement on general contract principles, arguing that the agreement is void and that the underlying dispute does not have to be arbitrated. For example, federal courts have invalidated arbitration clauses based on lack of consideration, ${ }^{64}$ unconscionability, ${ }^{65}$ and the adhesion contract doctrine. ${ }^{6}$ Applicable state law supplies the contract principles a party may use to invalidate agreements to arbitrate, provided, however, that the laws are general in nature and not aimed specifically at arbitration clauses. ${ }^{67}$ Arbitration agreements are thus placed "upon the same footing as other contracts."

58 See Part II.A.1.

59 See Part II.A.3.

60473 US 614 (1985).

61 See id at 625-26; Part II.A.2.

62 See Part II.A.3.

639 USC $\$ 2$.

64 See, for example, Hull v Norcom, Inc, 750 F2d 1547, 1550 (11th Cir 1985) (invalidating an arbitration agreement in which only one party was obligated to submit controversies to arbitration).

65 See, for example, Geiger $v$ Ryan's Family Steak Houses, Inc, 134 F Supp 2d 985, 999 (S D Ind 2001) (invalidating as unconscionable an arbitration agreement whose rights and obligations defendant had misrepresented and plaintiff had misunderstood).

66 See, for example, Ticknor v Choice Hotels International, Inc, 265 F3d 931, 939-41 (9th Cir 2001) (refusing to enforce an arbitration clause contained in a pre-printed standard form agreement drafted by one party).

67 See Doctor's Associates, Inc v Casarotto, 517 US 681, 686-87 (1996): 
An arbitration agreement is often not a stand-alone contract between two parties, but rather a short clause inserted in a much broader contract such as a contract for sale of goods or an employment agreement. ${ }^{69}$ Under Section 4 of the FAA, a federal district court must grant a motion to compel arbitration once it is "satisfied that the making of the agreement for arbitration or the failure to comply therewith is not an issue." ${ }^{, 0}$ This section has been interpreted to mean that challenges to arbitration agreements based on general contract doctrines must be made to the arbitration clause specifically, and not the broader contract generally. "The Supreme Court explains with an example:

[I]f the claim is fraud in the inducement of the arbitration clause itself - an issue which goes to the making of the agreement to arbitrate-the federal court may proceed to adjudicate it. But the statutory language does not permit the federal court to consider claims of fraud in the inducement of the contract generally.

These latter claims of general contract validity are left for determination through the arbitration. ${ }^{73}$

2. Challenges based on inability to vindicate statutory rights.

A second type of challenge to an arbitration agreement that may be raised prior to arbitration arises when the underlying dispute involves the federal statutory rights of one of the parties. Disputes by parties who are bound by arbitration agreements frequently involve rights under Title VII, ${ }^{74}$ the Truth in Lending Act, ${ }^{75}$ and civil RICO

[S]tate law may be applied if that law arose to govern issues concerning the validity, revocability, and enforceability of contracts generally. Thus, generally applicable contract defenses, such as fraud, duress, or unconscionability, may be applied to invalidate arbitration agreements without contravening $\S 2$ [of the FAA]. Courts may not, however, invalidate arbitration agreements under state laws applicable only to arbitration provisions.

(citations omitted).

68 Id at 687, quoting Scherk v Alberto-Culver Co, 417 US 506, 511 (1974).

69 See, for example, Prima Paint Corp v Flood and Conklin Manufacturing Co, 388 US 395 , 398 (1967) (involving a consulting contract containing the following arbitration clause: "Any controversy or claim arising out of or relating to this [consulting contract], or the breach thereof, shall be settled by arbitration in the City of New York, in accordance with the rules then obtaining of the American Arbitration Association.").

709 USC $\$ 4$.

71 See Prima Paint Corp, 388 US at 403-04 (holding that a federal court may consider only issues relating to the making or performance of the arbitration clause when determining whether to compel arbitration under 9 USC $\$ 4$ ).

72 Id at $403-04$.

73 See id at 406 (noting that the issue of fraud in making the entire contract, of which the arbitration agreement was a part, was an issue for arbitration).

74 See, for example, Alexander v Gardner-Denver Co, 415 US 36 (1974) (involving a Title VII employment discrimination claim made by an employee who was party to an arbitration 
statutes. ${ }^{76}$ The Supreme Court recently affirmed the possibility of arbitrating such disputes based on statutory rights," noting that "claims arising under a statute designed to further important social policies may be arbitrated 'so long as the prospective litigant effectively may vindicate [his or her] statutory cause of action in the arbitral forum."” This language opens the door to allow a party to escape arbitration of a dispute involving statutory rights by claiming that the arbitral forum does not allow effective vindication of those rights. Some federal courts have been receptive to this argument.

For example, in Graham Oil Co v Arco Products $\mathrm{Co}^{79}$ the Ninth Circuit overturned a lower court's dismissal of a dispute that was ostensibly governed by an arbitration agreement. ${ }^{80}$ The dispute involved a gasoline distribution agreement between an oil producer and a distributor. ${ }^{\text {s1 }}$ These relationships are normally governed by the Petroleum Marketing Practices Act ("PMPA"), which grants parties to a distribution agreement particular benefits such as the right to recover exemplary damages and attorneys' fees. The arbitration clause at issue in Graham Oil, which covered "any dispute or controversy relating to or arising out of the agreement," ${ }^{4}$ forfeited several of these rights. The court noted that nothing prevents parties from arbitrating statutory rights generally and that rights under the PMPA could be submitted to arbitration. ${ }^{\text {s. }}$ In this case, however, the court found that the arbitration agreement, in forfeiting statutory benefits, violated both the purpose and the specific terms of the PMPA.

agreement with his employer).

75 See, for example, Green Tree Financial Corp-Alabama v Randolph, 531 US 79 (2000) (involving claims under the Truth in Lending Act made by borrower against her lender where the financing agreement included an arbitration clause).

76 See, for example, Shearson/American Express, Inc v McMahon, 482 US 220 (1987) (involving civil RICO claims asserted against a brokerage firm by its customers who had signed customer agreements that contained arbitration clauses).

77 See Green Tree, 531 US at 84 (holding that a party's claims under Truth in Lending Act and Equal Credit Opportunity Act were subject to arbitration agreement). See also Gilmer $v$ Interstate/Johnson Lane Corp, 500 US 20, 26 (1991) ("It is by now clear that statutory claims may be the subject of an arbitration agreement.").

78 Green Tree,531 US at 90, quoting Mitsubishi, 473 US at 637. See also Mitsubishi, 473 US at 628 ("By agreeing to arbitrate a statutory claim, a party does not forgo the substantive rights afforded by the statute; it only submits to their resolution in an arbitral, rather than a judicial, forum.").

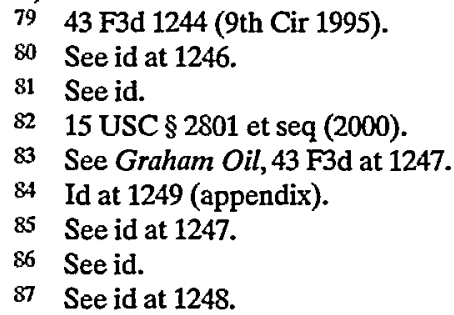


Similarly, the Eleventh Circuit has refused to compel arbitration of a dispute involving the statutory rights of one of the parties. In Paladino v Avnet Computer Technologies, Inc, an employer attempted to compel arbitration after an employee filed a Title VII claim. The arbitration agreement covered "any controversy or claim arising out of or relating to [the] employment," but indicated that the arbitrator was authorized only to award damages for breach of contract and had "no authority whatsoever to make an award of other damages." This limitation on damages would have precluded any possibility of receiving Title VII damages in the arbitration, and was thus "fundamentally at odds with the purposes of Title VII." compel arbitration of the employee's Title VII claims because she would not be able to vindicate effectively her statutory claims in the arbitral forum in the absence of the arbitrator's authority to award any damages for Title VII violations.

\section{Justifications for allowing challenges prior to arbitration.}

The fact that challenges to arbitration based on contractual grounds are heard prior to arbitration is based on the text of Section 2 of the FAA. ${ }^{.3}$ Because arbitration is a matter of contract, the authority of an arbitrator to resolve disputes arises only from the agreement of the parties. ${ }^{4}$ Before a reluctant party can be forced to submit to arbitration, it must be judicially determined that the parties have contractually agreed to be so bound. ${ }^{95}$ This inquiry should occur prior to arbitration for two reasons. First, arbitrators have no authority to hear disputes absent a valid arbitration agreement. Second, the outcome of such an inquiry does not depend on what happens during the arbitration. Unlike challenges to arbitration based on "evident partiality" or "fundamental unfairness," which attack the arbitration proceeding itself, contractual challenges to the arbitration agreement rely solely

88134 F3d 1054 (11th Cir 1998).

89 See id at 1056.

90 Id.

91 Id at 1060.

92 See id.

93 See 9 USC $\$ 2$ (stating that an agreement to arbitrate "shall be valid, irrevocable, and enforceable, save upon such grounds as exist at law or in equity for the revocation of any contract").

94 See $A T \& T$ Technologies, Inc v Communications Workers of America, 475 US 643, 648-49 (" $[A]$ rbitrators derive their authority to resolve disputes only because the parties have agreed in advance to submit such grievances to arbitration.").

95 See Sydnor v Conseco Financial Servicing Corp, 252 F3d 302, 305 (4th Cir 2001) ("Congress did not intend for the FAA to force parties who had not agreed to arbitrate into a nonjudicial forum, and therefore, federal courts must first decide whether the parties entered into an agreement to arbitrate their disputes.").

96 See Part II.B.3. 
on events unrelated to the arbitration proceeding. Contractual challenges focus on whether there was a valid contractual agreement to arbitrate.

Challenges based on the inability to vindicate statutory rights effectively are not derived directly from the FAA. Instead, these challenges are based on a line of cases decided by the Supreme Court, including Gilmer $v$ Interstate/Johnson Lane Corp ${ }^{97}$ and Mitsubishi. ${ }^{93}$ The treatment of statutory rights is different because of the public interest in the resolution of disputes over statutory rights-an interest that is separate from private parties' interest in resolving a dispute between themselves. ${ }^{97}$ In order for these rights to be submitted to arbitration, the arbitration must allow effective vindication of them. Any arbitration of a statutory claim that did not allow for effective vindication of rights would "conflict[] with the statute's purpose of both providing individual relief and generally deterring unlawful conduct through the enforcement of its provisions." ${ }^{100}$

While in some cases post-arbitration judicial review could be sufficient to ensure effective vindication of statutory rights, ${ }^{101}$ in at least some cases such post-arbitration review would not be sufficient. For example, in Cole v Burns International Security Services, ${ }^{\text {,ea }}$ the D.C. Circuit placed importance on the fact that an arbitration agreement required a written opinion when it determined that the arbitration at issue would allow effective vindication of Title VII claims. ${ }^{103}$ Presumably, post-arbitration judicial review of a proceeding that had resulted in no written opinion would be impossible, and thus would not offer adequate protection of statutory rights. In such cases, challenges alleging that arbitration would not allow effective vindication of statutory rights must be heard pre-arbitration.

97500 US 20 (1991).

98 See note 78 and accompanying text.

99 See Cole v Burns International Security Services, 105 F3d 1465, 1476 (DC Cir 1997) (stating that "a private agreement to arbitrate statutory claims" does not only affect the private parties, rather "there is a public interest in the manner in which the external-law norms are articulated and applied in the arbitral forum"), quoting Samuel Estreicher, Arbitration of Employment Disputes without Unions, 66 Chi Kent L Rev 753, 777 (1990).

100 Floss, 211 F3d 306, 313 (6th Cir 2000) (holding that the arbitration agreement between employer and employees was unenforceable because the employees received no consideration for their promise to submit disputes to arbitration).

101 See Gilmer, 500 US at 30-31, 32 n 4 (noting that plaintiff had failed to show that postarbitration review would be inadequate to guard against bias that would preclude effective vindication of his claims under the ADEA).

102105 F3d 1465 (DC Cir 1997).

103 See id at 1482. 


\section{B. Challenges Following Arbitration}

Section 10 of the FAA sets out the situations in which a party may challenge an arbitration award after the arbitration has been completed. ${ }^{104}$ An arbitration award may be vacated if it was procured by corruption or fraud, or there was bias or misconduct in the arbitration. ${ }^{105}$ In addition, several courts have endorsed the extra-statutory ground of "fundamental unfairness" for vacating an arbitration award. ${ }^{10,}$

Post-arbitration review of these types of challenges is justified on two main grounds. ${ }^{107}$ First, the text of Section 10 lists vacatur of an arbitration award as the only remedy. Second, determining whether there was individual bias or unfairness in a proceeding requires that the proceeding has actually taken place.

1. Vacatur based on "evident partiality" of the arbitrator.

Section 10(a)(2) of the FAA indicates that a federal district court may vacate an arbitration award if there was "evident partiality" in the arbitrator or arbitrators. ${ }^{108}$ The text of Section 10 implies that "evident partiality" must be shown by proof of actual bias, a rather high threshold. ${ }^{109}$ The Supreme Court addressed the meaning of "evident partiality" in Commonwealth Coatings Corp v Continental Casualty Co. ${ }^{110}$ In that case, a plurality of four justices found that arbitrators must avoid "even the appearance of bias" under the FAA. " However, while two other justices concurred in the result, they did not subscribe to the same "appearance of bias" standard as the plurality. ${ }^{12}$ As the

104 See 9 USC \$\$ 10(a)(1)-(4).

105 See id.

106 See, for example, Hoffman v Cargill, Inc, 59 F Supp 2d 861, 891-95 (N D Iowa 1999) (discussing the "fundamental unfairness" approach), revd 236 F3d 458 (8th Cir 2001) (finding that the facts did not meet the legal standard). See also Part II.B.2. This type of review looks only to the "fundamental unfairness" of the proceedings, not the "fundamental unfairness" of any determination or award by the arbitration panel. Hoffman, $59 \mathrm{~F}$ Supp $2 \mathrm{~d}$ at 892 .

107 See Part II.B.3.

1089 USC \$ $10(\mathrm{a})(2)$.

109 See Morelite Construction Corp v New York City District Council Carpenters Benefit Funds, 748 F2d 79, 84 (2d Cir 1984) (noting that the literal words of Section 10 suggest an actual bias standard, a standard it called "difficult, and indeed often impossible" to meet). See also Merit Insurance Co v Leatherby Insurance Co, 714 F2d 673, 681 (7th Cir 1983) ("Read literally, [Section 10(a)(2)] would require proof of actual bias.").

110393 US 145 (1968) (vacating an award rendered in an arbitration between a prime contractor and a subcontractor where one of the three arbitrators had a significant undisclosed business relationship with the prime contractor, despite the fact that there was no allegation of actual bias or fraud on the part of the arbitrator).

111 Id at 150 .

112 Id at 150-52 (White concurring) (noting that arbitrators should not be held to the same standards of judicial decorum as Article III judges, and that a business relationship between an arbitrator and a party should not result in automatic disqualification). 
Second Circuit noted, "much of [the plurality's] opinion must be read as dicta, and we are left in the dark as to whether an 'appearance of bias' will suffice to meet the seemingly more stringent 'evident partiality' standard of 9 U.S.C. $\$ 10 .{ }^{\prime 13}$

In navigating these murky waters, several circuit courts have adopted a standard somewhere between an "appearance of bias" standard and the "actual bias" standard that the text of Section 10 implies. ${ }^{14}$ This intermediate standard was expressly formulated by the Second Circuit in Morelite Construction Corp v New York City District Council Carpenters Benefit Funds:" "[W]e hold that 'evident partiality' within the meaning of 9 U.S.C. $\$ 10$ will be found where a reasonable person would have to conclude that an arbitrator was partial to one party to the arbitration." award made in an arbitration in which the arbitrator's father was a vice president of an international union of which one party was a member."

At least two circuits have expressly adopted the Second Circuit's Morelite formulation. ${ }^{118}$ Additionally, three other circuits have adopted a remarkably similar approach. Both the Ninth and Eleventh Circuits use a "reasonable impression of partiality" standard to evaluate claims of evident partiality under Section $10{ }^{119}$ The Seventh Circuit also has indicated that an arbitrator who "might reasonably be suspected of partiality" could be disqualified under Section 10(a)(2).

Under Section 10 therefore, a federal court may vacate an arbitration award if there was partiality on the part of the arbitrator. In examining whether there was partiality sufficient to vacate an award

113 Morelite Construction Corp, 748 F2d at 83.

114 See, for example, id at $83-84$ (reading "Section $10(b)$ as requiring a showing of something more than the mere 'appearance of bias' to vacate an arbitration award," while recognizing that "a standard for partiality as insurmountable as 'proof of actual bias'-as the literal words of Section 10 might suggest," would not be practical).

115748 F2d 79 (2d Cir 1984).

116 Id at 84.

117 See id ("We know nothing more about the relationship between Patrick Campbell, Jr. and Patrick Campbell, Sr. except that the former is the latter's son.... We cannot in good conscience allow the entering of an award grounded in what we perceive to be such unfairness.").

118 See Peoples Security Life Insurance Co v Monumental Life Insurance Co, 991 F2d 141, 146 (4th Cir 1993) (stating that a plaintiff "must show that 'a reasonable person would [] conclude that an arbitrator was partial' to the other party to the arbitration"), quoting Apperson v Fleet Carrier Corp, 879 F2d 1344, 1358 (6th Cir 1989) (citing Morelite).

119 Scott v Prudential Securities, Inc, 141 F3d 1007, 1015 (11th Cir 1998) ("To vacate an arbitration award for evident partiality, the moving party must present evidence that would support a reasonable impression of partiality on the arbitrator's behalf.") (citation omitted); Schmitz v Zilveti, 20 F3d 1043, 1047 (9th Cir 1994) ("'Reasonable impression of partiality' ... is the best expression of the Commonwealth Coatings court's holding.").

120 Merit Insurance, $714 \mathrm{~F} 2 \mathrm{~d}$ at 681 (indicating that Section 10(a)(2) could be read to disqualify an arbitrator reasonably suspected of partiality). 
under this section, courts have adopted a standard somewhere between "appearance of bias" and "actual bias," adopting some variation of a "reasonable impression of bias" standard.

\section{Vacatur based on "fundamental unfairness" of the arbitration.}

In addition to the statutory grounds for vacatur in Section 10 , some courts have embraced the idea that an award based on an arbitration that was not "fundamentally fair" may be vacated." Most circuits take the view that the fundamental fairness test is simply an offshoot of the Section 10(a)(3) requirement that the arbitrator be free from "misbehavior by which the rights of any party have been prejudiced." $"$ For example, in Hoteles Condado Beach, La Concha and Convention Center v Union de Tronquistas Local 901, ${ }^{123}$ when an arbitrator accepted into evidence the trial transcript of a criminal proceeding related to the arbitration dispute, but then refused to give any weight to that evidence, the First Circuit held that this refusal justified vacatur of the arbitration award. ${ }^{124}$ The court cited Section $10(\mathrm{a})(3)$ and concluded that "[v]acatur is appropriate only when the exclusion of relevant evidence so affects the rights of a party that it may be said that he was deprived of a fair hearing.,"125

One circuit, on the other hand, adopted the fundamental fairness test as an extra-statutory ground for vacating an arbitration award. The Tenth Circuit has distinguished vacatur based on fundamental unfairness from vacatur based on Section 10, holding that "[a]n arbitrator's decision may be set aside only for reasons stated in the FAA, or

121 See, for example, Bowles Financial Group, Inc v Stifel, Nicolaus \& Co, Inc, 22 F3d 1010, 1012-13 (10th Cir 1994) (collecting cases).

1229 USC \& 10(a)(3).

123763 F2d 34 (1st Cir 1985).

124 Id at 40.

125 Id (citation omitted). Other courts resting the "fundamental fairness" doctrine on Section 10(a) include the Second, Third, Fourth, Fifth, Sixth, and Eighth Circuits. See Bell Aerospace Company Division of Textron, Inc v Local 516, 500 F2d 921, 923 (2d Cir 1974) (interpreting Section 10 to require that an arbitrator "need only grant the parties a fundamentally fair hearing"); Newark Stereotypers' Union No 18 v Newark Morning Ledger Co, 397 F2d 594, 599 (3d Cir 1968) (holding that under Section 10(a)(3), an error that requires vacatur of an award "must be one that ... so affects the rights of a party that it may be said that he was deprived of a fair hearing"); Gallus Investments, LP v Pudgie's Famous Chicken, Ltd, 134 F3d 231, 234 (4th Cir 1998) (supposing without deciding that there may exist some situation where an arbitrator's blatant use of evidence "might be so fundamentally unfair as to violate § 10"); Forsythe International, SA v Gibbs Oil Co, 915 F2d 1017, 1020 (5th Cir 1990) (holding that any one of the statutory grounds in Section 10 may justify vacatur, but positing the question for review as "whether the arbitration proceedings were fundamentally unfair"); National Post Office Mailhandlers $v$ United States Postal Service, 751 F2d 834, 841 (6th Cir 1985) (holding that the standard for review of arbitration proceedings under Section 10(a)(3) is "whether a party to arbitration has been denied a fundamentally fair hearing"); Grahams Service Inc v Teamsters Local 975, 700 F2d 420, 422 (8th Cir 1982) (adopting the interpretation of Section 10(a)(3) given by the Third Circuit in Newark Stereotypers' Union). 
for a small number of reasons created by the courts, including awards ... where the arbitrators failed to conduct a fundamentally fair hearing." ${ }^{126}$

Regardless of its foundation, a majority of circuits have recognized fundamental unfairness as a ground for vacating an arbitration award. The basic requirements of fundamental fairness are "notice, opportunity to be heard and to present relevant and material evidence and argument before the decision makers, and that the decision makers are not infected with bias." ${ }^{\text {127 }}$ Thus, whether the test is justified as an interpretation of the Federal Arbitration Act or as an extrastatutory, judicially-created doctrine, most courts recognize that an arbitration award may be vacated if it is the result of a proceeding that was fundamentally unfair.

3. Justifications for postponing challenges until after arbitration.

Some courts have held that challenges based on "evident partiality" and "fundamental unfairness" must be postponed until after the arbitration has been completed. ${ }^{223}$ This requirement comes in part from the text of Section 10 of the FAA, which allows a district court to "make an order vacating the award." If challenges to arbitration based on Section 10, such as "evident partiality" and "fundamental unfairness" challenges, can only be redressed through vacatur of an award, they clearly cannot be redressed until after arbitration. ${ }^{130}$ In addition to this textual argument, postponement makes sense because any bias will only manifest itself in the actual arbitration. ${ }^{131}$ Permitting partiality or unfairness challenges prior to arbitration would open the

126 Keil-Koss v Cigna, 2000 US App LEXIS 8840, *5 (10th Cir). But see Hoffman v Cargill,

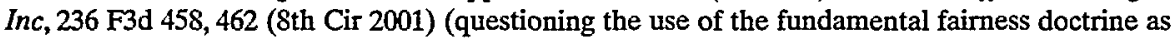
an extra-statutory justification for vacatur).

127 Bowles, 22 F3d at 1013. See also National Boatland, Inc v ITT Commercial Finance Corp, 2000 US App LEXIS 24783, *6 (6th Cir), citing Bowles; Ramirez-de-Arellano v American Airlines, Inc, 133 F3d 89, 91 (1st Cir 1997) ("Arbitration proceedings must meet the minimal requirements of fairness - adequate notice, a hearing on the evidence, and an impartial decision by the arbitrator.") (quotation marks omitted); Sunshine Mining Co v United Steelworkers of America, 823 F2d 1289, 1295 (9th Cir 1987).

128 See Smith, 233 F3d at 506 (stating that the "time to challenge an arbitration, on whatever grounds, including bias, is when the arbitration is completed and an award rendered"); Michaels $v$ Mariforum Shipping, SA, 624 F2d 411, 414 n 4 (2d Cir 1980) ("[I]t is well established that a district court cannot entertain an attack upon the qualifications or partiality of arbitrators until after the conclusion of the arbitration and the rendition of an award.").

1299 USC \$ 10(a).

130 See Folse $v$ Richard Wolf Medical Instruments Corp, 56 F3d 603, 605 (5th Cir 1995) ("By its own terms, $\$ 10$ authorizes court action only after a final award is made by the arbitrator.") (emphasis added).

131 See Crim v Pepperidge Farm, Inc, 32 F Supp 2d 326, 330 (D Md 1999) (stating that arbitrators should be "given a chance to demonstrate that they will participate in the arbitration process in a fair, honest and good-faith manner") (quotation marks omitted). 
floodgates to litigation in circumstances in which the parties may not face bias directly. ${ }^{132}$ Such litigation would be time-consuming and potentially fruitless considering the difficulty in showing partiality or unfairness absent an award, or at least a proceeding, that reflects such bias. $^{133}$

This type of expensive delay runs "counter to the purpose of the arbitration process in general, and the Federal Arbitration Act in particular, which is to relieve congestion in the courts and to provide parties with an alternative method for dispute resolution that would be speedier and less costly than litigation." ${ }^{134}$ Additionally, if a district court entertains a partiality or unfairness challenge prior to arbitration, it may interfere with the choice made by parties to an arbitration agreement to "trade off certain procedural safeguards . . . against hoped-for savings in time and expense."135

\section{PeRmitting Institutional Bias Challenges PRIOR TO ARBITRATION}

This Comment proposes that courts should entertain institutional bias claims prior to arbitration. The FAA clearly indicates that parties may challenge arbitration agreements on general contract grounds, and as will be shown, there are legitimate contractual grounds on which to base institutional bias challenges to arbitration. Further, for disputes involving statutorily created rights, Supreme Court precedent involving "effective vindication" provides another basis for launching an attack on structurally biased arbitration proceedings. Because institutional bias challenges can be characterized as challenges based on either contractual grounds or an inability to vindicate statutory rights, the justifications for allowing those types of challenges to proceed prior to arbitration ${ }^{136}$ apply to the institutional bias challenges as well. The fact that institutional bias underlies the contractual or ineffective vindication challenge does not change the fundamental nature of the challenge.

132 See id ("If the parties are allowed to challenge the arbitrator chosen by their opponents based merely on the appearance of impropriety before [the arbitration] ... then the floodgates to litigation will be open."); Aviall, Inc v Ryder System, Inc, 913 F Supp 826, 833 (S D NY 1996) ("[A]llowing courts to review before the fact the partiality of arbitrators would spawn endless litigation."), affd, 110 F3d 892 (2d Cir 1997).

133 See Aviall, $913 \mathrm{~F}$ Supp at 833 ("In most cases it is inappropriate and difficult to determine the partiality of an arbitrator absent an award that reflects alleged bias.").

134 Crim, 32 F Supp $2 d$ at 330 (quotation marks omitted).

135 Smith, 233 F3d at 506 (noting that the right to challenge the arbitral forum on grounds other than those provided for by the FAA was one of the procedural rights given up by plaintiff when she agreed to the arbitration clause).

136 See Part II.A.3. 
Both of these methods - basing an institutional bias challenge on either a contractual or ineffective vindication claim-allow parties to avoid arbitration to which they ostensibly agreed to submit disputes. This apparently runs counter to the "national policy favoring arbitration," which encourages disputes to be resolved in favor of arbitration. However, it is not clear that post-arbitration court proceedings would be able to address institutional bias challenges sufficiently.

\section{A. Institutional Bias Challenges Based on General Contract Principles}

Contract grounds for challenging arbitration agreements prior to arbitration are well-suited for application to charges of institutional bias. Consider a claim of unconscionability. In Indiana, for example, a claim of unconscionability requires that there was a great disparity in bargaining power that led the weaker party to sign the contract unwillingly or unaware of its terms, and that the contract was "such that no sensible man not under delusion, duress, or in distress would make [it], and such as no honest and fair man would accept [it].",138 It is easy to imagine a situation in which an arbitration agreement creates a process or chooses a forum that is institutionally biased against one party such that no sensible person in that party's situation would agree to the arbitration. If there exists great disparity in the bargaining strength of two parties whereby one party is forced to accept the arbitration that is biased against it, the agreement arguably could be considered unconscionable. ${ }^{139}$ If a party understood the bias at the time of entering the agreement it should not be allowed to argue unconscionability, ${ }^{40}$ but a party should not be bound to arbitrate in a forum, the inherent bias of which it was unaware.

Lack of consideration may also be a valid contract principle on which to rest an institutional bias challenge. Generally, one party's promise to submit disputes to arbitration can serve as consideration for the other party's promise to do the same. ${ }^{141}$ However, if the arbitra-

137 Southland Corp $v$ Keating, 465 US 1, 10 (1984).

138 Geiger v Ryan's Family Steak Houses, Inc, 134 F Supp 2d 985, 997 (S D Ind 2001), citing Weaver v American Oil Co, 257 Ind 458, 276 NE2d 144, 146 (1971).

139 See, for example, Geiger, $134 \mathrm{~F}$ Supp 2d at 999-1001 (holding that a high school graduate seeking a job at a restaurant could not understand or formulate questions about the arbitration procedure to which she was binding herself and which the court found structurally biased in the restaurant's favor).

140 See, for example, Woods v Saturn Distribution Corp, 78 F3d 424, 428 (9th Cir 1996) (rejecting an unconscionability claim where, at the time of signing an arbitration agreement, the party understood the arbitration procedure and the relationship of arbitrators to the other party).

141 See, for example, Matterhorn, Inc v NCR Corp, 763 F2d 866, 869 (7th Cir 1985) ("If the agreement of one party to arbitrate disputes is fully supported by the other party's agreement to 
tion is heavily biased in favor of one party, it is as if that party is giving up nothing in exchange for the other party's promise.

Two circuit courts have recently upheld a similar argument. ${ }^{122}$ In these cases, the finding of lack of consideration was based on the fact that one party had the ability to modify the arbitration rules and procedures unilaterally without notification or consent of the other party. ${ }^{143}$ There is little functional difference between an arbitral forum that is systematically biased in favor of one party by its nature and an arbitral forum that can be made that way through the unilateral action of that party.

Therefore, if a party's promise to arbitrate in a forum that it can change unilaterally to favor it is not consideration, and this is functionally equivalent to a party's promise to arbitrate in a forum that is already institutionally biased in its favor, then a party's promise to arbitrate in the latter forum is not consideration. Lack of consideration based on institutional bias is thus a legitimate contractual ground on which to challenge an arbitration agreement.

\section{B. Institutional Bias Challenges Based on Inability to Vindicate Statutory Rights}

With respect to arbitration of claims involving statutory rights, such as Title VII or civil RICO claims, the "effective vindication" line of cases provides a solid legal basis for institutional bias challenges prior to arbitration proceedings. ${ }^{145}$ With respect to arbitration of statu-

do likewise, there is no need to look elsewhere in the contract for consideration for the agreement to arbitrate.").

142 See Penn v Ryan's Family Steak Houses, Inc, 269 F3d 753, 759-60 (7th Cir 2001) (finding a lack of consideration in an arbitration agreement where the party providing the arbitral forum had unfettered discretion in choosing the nature of that forum); Floss, 211 F3d at 315-16 (same).

143 See Penn, 269 F3d at 759-60; Floss, 211 F3d at 315-16.

144 Any difference between the two scenarios seems to rest on the difference between the contract doctrines of nominal consideration and illusory promise. Penn and Floss invalidated arbitration agreements based on an illusory promise: The employer/arbitrator's ability to choose the fundamental nature of the arbitration forum made its promise to submit to arbitration illusory. See Penn, 269 F3d at 760 ("[T] he EDS Ryan's contract [] does nothing to limit EDS's ability to amend its procedures, reinforcing our opinion that its promise to Penn is unenforceable and illusory."); Floss, 211 F3d at 316 ("EDSI's right to choose the nature of its performance renders its promise illusory."). See also Restatement (Second) of Contracts $\$ 77$ (1979) (stating that "[a] promise ... is not consideration if by its terms the promisor ... reserves a choice of alternative performances"). Agreement to submit to arbitration that is institutionally biased in one's favor would technically not be considered an illusory promise because the promisor does not retain a choice over the nature of its performance. However, if a party is nearly assured of prevailing in arbitration, its promise to submit to arbitration in exchange for another party's promise to submit is functionally worthless. See Restatement (Second) of Contracts $\S 71$, comment b ("[A] mere pretense of bargain does not suffice [to create a contract], as ... where the purported consideration is merely nominal."). Though nominal consideration is not technically the same as illusory promise, both fall under the general rubric of lack of consideration.

145 See Part II.A.2. 
tory rights, the Supreme Court has indicated that courts should refuse to compel arbitration when parties will not be able to vindicate their statutory rights effectively. ${ }^{1+5}$ Various circuit courts have held that agreements explicitly limiting the types or amounts of remedies available to parties to arbitration do not allow effective vindication of statutory rights. ${ }^{127}$ It is a small step to hold that an arbitration that is inherently biased against a party asserting statutory claims also does not allow for the effective vindication of those claims. There is little relevant difference between an arbitration agreement that explicitly states that an arbitrator cannot award exemplary damages and an arbitration agreement that says nothing about exemplary damages, but submits disputes to a forum that in practice never awards them.

\section{Insufficiency of Post-Arbitration Challenges to Address Institutional Bias}

The two post-arbitration challenges that are potentially applicable to institutional bias challenges are measured by the "evident partiality" and "fundamental unfairness" standards. One could argue that an institutional bias challenge is similar enough to these postarbitration challenges that it too should be heard only after an arbitration is complete. Further examination of the "evident partiality" and "fundamental unfairness" challenges, however, shows that neither would provide an adequate remedy for victims of institutional bias.

First, while the "evident partiality" standard may be sufficient to challenge bias of individual arbitrators, it is not clear that such a standard would allow remedy of certain structural biases. For a court to vacate an award for "evident partiality," a party must allege partiality that is "direct, definite, and capable of demonstration." strate direct and definite partiality, a plaintiff must show "specific facts" evidencing that an award was tainted by the arbitrators' partiality." The problem with trying to use the "evident partiality" remedy for challenging the institutional biases of an arbitration forum is that many types of structural bias will never result in specific facts showing that an individual arbitrator was partial.

146 See id.

147 See id.

148 See Part II.B.1.

149 See Part II.B.2.

150 Andersons, Inc v Horton Farms, Inc, 166 F3d 308, 329 (6th Cir 1998). See also Harter v lowa Grain Co, 220 F3d 544, 553 (7th Cir 2000) ("We have stated that 'evident partiality' exists when an arbitrator's bias is direct, definite and capable of demonstration rather than remote, uncertain, or speculative.") (quotation marks omitted); Scott v Prudential Securities, Inc, 141 F3d 1007,1015 (11th Cir 1998).

151 Andersons, 166 F3d at 329. 
For example, the Geist study of ICANN's dispute resolution system found that there are two types of arbitrators: those who strictly interpret ICANN rules, and those who take a more liberal approach to the rules. ${ }^{152}$ None of these arbitrators may exhibit evident partiality on an individual basis. Strict interpretation of the rules may favor trademark holders while looser interpretation may favor domain name registrants, but an arbitrator may not be biased toward one party simply because he favors one interpretive philosophy over the other. Under these circumstances, no "specific facts" evidencing arbitrator partiality could be alleged. However, if the organization providing the arbitration consistently assigns arbitrators favoring strict interpretation when it claims to assign arbitrators randomly, ${ }^{153}$ the arbitration may be seriously biased against one party. This type of bias would not be addressed sufficiently by an evident partiality standard that looked solely to the bias of individual arbitrators and ignored less concrete forms of bias diffused throughout the entire arbitral system.

Indeed, institutional bias challenges made in the form of motions to vacate for evident partiality have not met with much success. ${ }^{14} \mathrm{Be}-$ cause evident partiality has been interpreted to mean something beyond a mere appearance of bias, ${ }^{155}$ the inability of some types of structural bias, such as the ICANN bias described above, to evidence "specific facts" of actual bias in any particular case leaves such structural bias outside the reach of vacatur based on evident partiality. ${ }^{15}$

Similarly, a "fundamental unfairness" inquiry appears insufficient to address concerns of institutional bias after arbitration. The fact that fundamental fairness requires "notice, opportunity to be heard and present relevant and material evidence and argument before the decision makers, and that the decision makers are not infected with bias" implies that relief could be granted following arbitrations in which institutional bias resulted in an unfavorable award. However, the "fundamental unfairness" approach suffers from the same shortcomings as the "evident partiality" approach with respect to institutional bias. Here too the problem arises in situations such as the ICANN example

152 Geist, How Bias Besets Domain Cases, The Globe and Mail at B12 (cited in note 30).

153 See note 35.

154 See, for example, Harter, 220 F3d at 555-57 (holding that allegations of institutional bias in the NGFA, even if true, would not establish the direct, definite bias required for vacatur under evident partiality provision); Andersons, $166 \mathrm{F3d}$ at 329-30 (refusing to vacate arbitration award despite allegations of "systemic defects" in NGFA arbitration proceedings).

155 See Part II.B.1.

156 See Andersons, 166 F3d at 329 ("[T]he party seeking invalidation must demonstrate more than an amorphous institutional predisposition toward the other side; a lesser showing would be tantamount to an 'appearance of bias' standard.").

157 Bowles Financial Group, Inc v Stifel, Nicolaus \& Co, Inc, 22 F3d 1010, 1013 (10th Cir 1994). See also note 127 and accompanying text. 
in which institutional bias is diffused through higher levels rather than the individual arbitrators. To the extent that "fundamental unfairness" is simply an offshoot of the Section 10(a)(3) requirement that arbitrators be free from misconduct or other misbehavior, ${ }^{15 s}$ it will not address bias that is not directly manifested in the actions or behavior of individual arbitrators.

Further, even the Tenth Circuit, which considers the "fundamental fairness" doctrine outside the statutory boundaries of Section $10(a)(3)$, has been reluctant to declare an arbitral forum fundamentally unfair where, although the arbitration rules may create an unfair system, there is no specific violation of those rules by the arbitrators or the parties.

Again, the Tenth Circuit's "fundamental unfairness" approach would fail to address the ICANN bias at levels higher than the individual arbitrator. The justifications for postponing "evident partiality" and "fundamental unfairness" challenges simply do not apply to institutional bias challenges. Because the former challenges require showings of partiality or unfairness in the actual arbitration, it is only logical that an arbitration must have taken place. But as the ICANN example illustrates, institutional bias may be present and have adverse effects on one party without the bias ever manifesting itself in a directly observable event in the arbitration. Thus, delaying an institutional bias challenge until the proceeding is complete may add no new evidence.

Thus, the two approaches for post-arbitration vacatur that at first glance appear most helpful in providing relief for systemically biased arbitration proceedings-"evident partiality" and "fundamental unfairness"-seem insufficient to remedy such bias. Both approaches may address bias at the level of individual arbitrators, but fail to address bias one step removed at the institutional level.

\section{CONCLUSION}

Charges of institutional bias have been leveled against various arbitration organizations. When a party who has signed a pre-dispute arbitration agreement is faced with the specter of being forced to arbitrate a dispute in a forum that is biased against it, that party may wish to seek relief from a federal district court. Allegations of institutional bias may seem no different from charges of evident partiality or fun-

158 See note 122 and accompanying text.

159 See, for example, Bowles, 22 F3d at 1013-14 (holding that an aggrieved party had not proven that it was subjected to a fundamentally unfair hearing where opposing counsel had seemingly improper contact with the arbitrators, but where such contact_was not expressly prohibited by the broad procedural rules of the arbitration). 
damental unfairness, thus requiring delay until after arbitration before such allegations may be raised in court. However, this Comment points out important differences between these types of challenges, and further proposes that institutional bias claims map well with either contractual claims or claims of inability to vindicate statutory rights effectively. Thus, such challenges may be raised before the party is forced to submit to the allegedly biased arbitration proceedings. 